\title{
Perception of Dental Students about Tooth Carving in Dental Education at a Tertiary Level Health Care Facility
}

\author{
Diksha Singh ${ }^{1}$, Pragya Pandey ${ }^{2}$, S. Kudva ${ }^{3}$, Manish Kumar Singh ${ }^{4}$, Shaleen Chandra ${ }^{5}$ \\ ${ }^{1}$ Associate Professor,Oral pathology and Microbiology, Faculty of Dental Sciences, KGMU, Lucknow, UP, \\ ${ }^{2}$ Assistant Professor Department of Conservative Dentistry and Endodontics, ${ }^{3}$ Professor and Head, Department \\ of Oral and Maxillofacial Pathology, Srinivas Dental College, Mangalore, ${ }^{4}$ Assistant Professor, Department \\ of Community Medicine, Dr. RMLIMS, Lucknow, UP, ${ }^{5}$ Professor and Head, Oral pathology and Microbiology, \\ Faculty of Dental Sciences, KGMU, Lucknow, UP
}

\begin{abstract}
Tooth carving on wax/plaster/plastic to reproduce reference models of teeth is used to teach dental students anatomy of the tooth. There is a ongoing debate on value of tooth carving exercise in undergraduate dental curriculum. Perception of students on utility of tooth carving is important in planning dental curriculum.

Objective: The present study seeks to analyze the perception of undergraduate dental students about tooth carving, its relevance and utility in future clinical practice. The various aids preferred by them to learn dental carving.
\end{abstract}

Method: Student's perception was assessed using a self administered questionnaire.

Results: Total 58 students participated in the study ( 36 girls and 22 boys). Both male and female students perceived that video demonstration of tooth carving, a improved carver design and having a collection of 32 natural teeth in the department and attending workshops will help in more accurate and better understanding of tooth carving. More male students perceived that dental carving will be helpful in their clinical practice compared to females. Majority of students believed that the course content on carving was adequate. $90 \%$ of $3^{\text {rd }}$ year students perceived that attending workshops would improve their knowledge on carving compared to $66 \% 2^{\text {nd }}$ year students and the difference was found to be statistically significant. A higher proportion of $2^{\text {nd }}$ year students compared to $3^{\text {rd }}$ year students perceived that improved carver design would help them carve more accurately. More $3^{\text {rd }}$ year students felt that the course content on carving was adequate. Majority of students perceived that multimedia presentations were the most effective educational aid for teaching tooth carving. Majority of students perceived that having handouts of presentations and POP models will be beneficial to them in learning tooth carving.

Conclusion: There is a need to revise the curriculum emphasizing on the utility of tooth carving in clinical practice. Also there is a need to adopt new innovative method at teaching dental carving, improving on carver design and enriching the course content with emphasis on competency and skills since many students even after having exposure to carving felt the need for further workshops.

Keywords: Dental Carving, Perception, Survey.

\section{Corresponding Author:}

Dr. Pragya Pandey

Assistant Professor Department of Conservative

Dentistry and Endodontics.

e-mail: w.pragya78@gmail.com

\section{Introduction}

Dental anatomy, taught in the preclinical years forms the foundation of sound routine dental practice in later years. Students learn the external and internal morphology of each individual tooth and the relationship between teeth within the arch and between arches of both 
primary and permanent dentition. Tooth carving on wax/ plaster/plastic to reproduce reference models of teeth is used to teach dental students anatomy of the tooth. Carving has been advocated for developing cognitive and motor skills. ${ }^{1-2}$ By carving teeth anatomy, the dental student begins to develop psychomotor skills for restoring the teeth to proper form and function. ${ }^{2}$ Students acquire the knowledge to identify teeth, recognize and diagnose tooth anomalies and treat or manage dental pathology.

There is an on-going discussion about the value of tooth carving exercise in the undergraduate dental curriculum. Opinions vary on the effectiveness of the tooth carving exercise and its relevance to students' later dental practice. Perception of students on utility of tooth carving is important in planning dental curriculum.

The aim of this study was to analyze the perceived importance of tooth carving among undergraduate dental students during their training.

\section{Methodology}

The present study was a cross sectional survey carried out among $2^{\text {nd }}$ and $3^{\text {rd }}$ year dental undergraduate students exposed to tooth carving at a tertiary level dental care facility in central Uttar Pradesh. The $2^{\text {nd }}$ and $3^{\text {rd }}$ year students attending lectures of Oral Pathology and Microbiology, King George Medical University,were informed about the purpose of the study and were given a self administered questionnaire to assess their perception on 6 different parameters concerned with Tooth Carving. Students willing to participate in the study, after obtaining the informed consent from all the participant explaining the procedure, were then asked to fill the questionnaire and those not interested were asked to return the questionnaire blank at the end of the lecture. Questionnaire was kept anonymous. Students were asked to only mention but to mention their gender, age and year of BDS. Data was tabulated in Ms Excel and was analyzed using WHO Epi Info software. Statistical difference in perception of students was tested for gender and year of BDS using Chi Square test for proportion.

\section{Results}

A total of 58 dental students participated in the survey. Of the students surveyed 40 were $3^{\text {rd }}$ year dental students and the rest were $2^{\text {nd }}$ year students. All students had exposure to carving tooth. 38 students had carved complete set of teeth. Amongst students who had carved complete set of teeth 15 were from $2^{\text {nd }}$ year and 23 were from $3^{\text {rd }}$ year BDS.

\section{Table 1: Age and gender wise distribution of study participants}

\begin{tabular}{|l|c|c|}
\hline Age (Years) & Male & Female \\
\hline$\leq 20$ years & 3 & 7 \\
\hline $20-25$ years & 17 & 28 \\
\hline$>25$ years & 2 & 1 \\
\hline Total & $\mathbf{2 2}$ & $\mathbf{3 6}$ \\
\hline
\end{tabular}

Table- 1 shows the age and gender wise distribution of study participants. Total 58 students participated in the study of which 36 were girls and 22 were boys. Mean age of male and female study participants was 20.5 and 21.5 years, respectively. Majority of study participants,about three fourth i.e. 17 (77\%) boys and $28(77 \%)$ girls were aged between 20 to 25 years. About $19 \%$ of female study participants were less than 20 years of age compared to fewer boys about $13 \%$.

Table 2: Perception of dental students on tooth carving by gender

\begin{tabular}{|c|l|l|c|c|c|}
\hline S.No. & Parameters & Response & Male & Female & Chi Square, p value \\
\hline \multirow{2}{*}{1} & \multirow{2}{*}{$\begin{array}{l}\text { Video demonstration of tooth } \\
\text { would be more helpful }\end{array}$} & Yes & $18(82 \%)$ & $25(69.4 \%)$ & \\
\cline { 3 - 5 } & & No & $1(4.5 \%)$ & $4(11.1 \%)$ & $1.232, \mathrm{p}=0.54$ \\
\cline { 3 - 5 } & No Idea & $3(13.6 \%)$ & $7(19.4 \%)$ & \\
\hline \multirow{2}{*}{2} & \multirow{2}{*}{$\begin{array}{l}\text { Improved carver design would help } \\
\text { carve more accurately }\end{array}$} & Yes & $17(77.3 \%)$ & $28(77.7 \%)$ & $0.32, p=0.848$ \\
\cline { 3 - 5 } & & No & $2(9 \%)$ & $2(5.5 \%)$ & \\
\cline { 3 - 5 } & No Idea & $3(13.6 \%)$ & $6(16.7 \%)$ & \\
\hline
\end{tabular}




\begin{tabular}{|c|c|c|c|c|c|}
\hline S.No. & Parameters & Response & Male & Female & Chi Square, $p$ value \\
\hline \multirow{3}{*}{3} & \multirow{3}{*}{$\begin{array}{l}\text { Dental carving will be helpful in } \\
\text { my clinical practice }\end{array}$} & Yes & $18(82 \%)$ & $20(55.5 \%)$ & \multirow{3}{*}{$4.43, p=0.108$} \\
\hline & & No & $1(4.5 \%)$ & $2(5.5 \%)$ & \\
\hline & & No Idea & $3(13.6 \%)$ & $14(38.9 \%)$ & \\
\hline \multirow{3}{*}{4} & \multirow{3}{*}{$\begin{array}{l}\text { Collection of } 32 \text { natural teeth in } \\
\text { Dept will help more }\end{array}$} & Yes & $20(90.9 \%)$ & $33(91.6 \%)$ & \multirow{3}{*}{$0.15, p=0.927$} \\
\hline & & No & $1(4.5 \%)$ & $1(2.7 \%)$ & \\
\hline & & No Idea & $1(4.5 \%)$ & $2(5.5 \%)$ & \\
\hline \multirow{3}{*}{5} & \multirow{3}{*}{$\begin{array}{l}\text { Would attend workshops to } \\
\text { improve on my knowledge }\end{array}$} & Yes & $18(82 \%)$ & $32(88.9 \%)$ & \multirow{3}{*}{$0.57, p=0.75$} \\
\hline & & No & $3(13.6 \%)$ & $3(8.3 \%)$ & \\
\hline & & No Idea & $1(4.5 \%)$ & $1(2.7 \%)$ & \\
\hline \multirow{3}{*}{6} & \multirow{3}{*}{$\begin{array}{l}\text { Course content on carving was } \\
\text { adequate }\end{array}$} & Yes & $18(82 \%)$ & $30(83.3)$ & \multirow{3}{*}{$0.022, p=0.98$} \\
\hline & & No & $2(9 \%)$ & $3(8.3 \%)$ & \\
\hline & & No Idea & $2(9 \%)$ & $3(8.3 \%)$ & \\
\hline
\end{tabular}

Table 2 shows the comparison of perception of male and female dental students on tooth carving. No, significant difference was observed between male and female students with regard to their perception about tooth carving on 6 parameters studied. Both male and female students perceived that video demonstration of tooth carving would be more useful. Male students compared to females had a higher preference for video demonstration of tooth carving. About $77 \%$ i.e. three fourth of both male and female students believed that a improved carver design would help them carve tooth more accurately. While $82 \%$ male students perceived that dental carving will be helpful in their clinical practice, about $39 \%$ (i.e. more than one third) of female students had no idea, whether dental carving will be helpful in their clinical practice. Majority of male and female students about $90 \%$ perceived that having a collection of 32 natural teeth in the department will help more in better understanding of tooth carving. About $82 \%$ of both male and female students perceived that course content on carving was adequate. However, $10 \%$ students did not agree to the same and reasons for the same needs to be looked in. Majority of both male and female students were of the opinion that attending workshops would improve their knowledge of carving. More female students compared to males were interested in attending workshop on tooth carving.

Table 3: Perception of dental students on tooth carving by year of BDS

\begin{tabular}{|c|c|c|c|c|c|}
\hline S.No. & Parameters & Response & $2^{\text {nd }}$ Year & $3^{\text {rd }}$ Year & Chi Square, $p$ value \\
\hline \multirow{3}{*}{1} & \multirow{3}{*}{$\begin{array}{l}\text { Video demonstration of tooth } \\
\text { would be more helpful }\end{array}$} & Yes & $12(66.6 \%)$ & $29(72.5 \%)$ & \multirow{3}{*}{$\begin{array}{c}0.95 \\
\mathrm{p}=0.62\end{array}$} \\
\hline & & No & $4(22.2 \%)$ & $5(12.5 \%)$ & \\
\hline & & No Idea & $2(11.1 \%)$ & $6(15 \%)$ & \\
\hline \multirow{3}{*}{2} & \multirow{3}{*}{$\begin{array}{l}\text { Improved carver design would } \\
\text { help carve more accurately }\end{array}$} & Yes & $15(83.3 \%)$ & $30(75 \%)$ & \multirow{3}{*}{$\begin{array}{c}0.50 \\
\mathrm{p}=0.77\end{array}$} \\
\hline & & No & $1(5.5 \%)$ & $3(7.5 \%)$ & \\
\hline & & No Idea & $2(11.1 \%)$ & $7(17.5 \%)$ & \\
\hline \multirow{3}{*}{3} & \multirow{3}{*}{$\begin{array}{l}\text { Dental carving will be helpful in } \\
\text { my clinical practice }\end{array}$} & Yes & $12(66.6 \%)$ & $26(65 \%)$ & \multirow{3}{*}{$\begin{array}{c}0.07 \\
\mathrm{p}=0.96\end{array}$} \\
\hline & & No & $1(5.5 \%)$ & $3(7.5 \%)$ & \\
\hline & & No Idea & $5(27.8 \%)$ & $11(27.5 \%)$ & \\
\hline
\end{tabular}




\begin{tabular}{|c|c|c|c|c|c|}
\hline S.No. & Parameters & Response & $2^{\text {nd }}$ Year & $3^{\text {rd }}$ Year & Chi Square, p value \\
\hline \multirow{3}{*}{4} & \multirow{3}{*}{$\begin{array}{l}\text { Collection of } 32 \text { natural teeth in } \\
\text { Dept will help more }\end{array}$} & Yes & $17(94.4 \%)$ & $36(90 \%)$ & \multirow{3}{*}{$0.31, p=0.576$} \\
\hline & & No & 0 & 0 & \\
\hline & & No Idea & $1(5.5 \%)$ & $4(10 \%)$ & \\
\hline \multirow{3}{*}{5} & \multirow{3}{*}{$\begin{array}{l}\text { Would attend workshops to } \\
\text { improve on my knowledge }\end{array}$} & Yes & $12(66.6 \%)$ & $36(90 \%)$ & \multirow{3}{*}{$7.86, p=0.005$} \\
\hline & & No & $6(33.3 \%)$ & $2(5 \%)$ & \\
\hline & & No Idea & 0 & $2(5 \%)$ & \\
\hline \multirow{3}{*}{6} & \multirow{3}{*}{$\begin{array}{l}\text { Course content on carving was } \\
\text { adequate }\end{array}$} & Yes & $13(72.2 \%)$ & $35(87.5 \%)$ & \multirow{3}{*}{$2.49, \mathrm{p}=0.286$} \\
\hline & & No & $2(11.1 \%)$ & $3(7.5 \%)$ & \\
\hline & & No Idea & $3(16.6 \%)$ & $2(5 \%)$ & \\
\hline
\end{tabular}

Table 3 shows the comparison of perception of $2^{\text {nd }}$ year and $3^{\text {rd }}$ year dental students on tooth carving. No, significant difference was observed between $2^{\text {nd }}$ year and $3^{\text {rd }}$ year students with regard to their perception about tooth carving on the parameters studied (5 out of 6), except for their perception on attending workshops would improve their knowledge of carving. $90 \%$ of $3^{\text {rd }}$ year students perceived that attending workshops would improve their knowledge on carving compared to $66 \% 2^{\text {nd }}$ year students. A higher proportion of $2^{\text {nd }}$ year students compared to $3^{\text {rd }}$ year students perceived that improved carver design would help them carve more accurately. More $3^{\text {rd }}$ year students felt that the course content on carving was adequate.

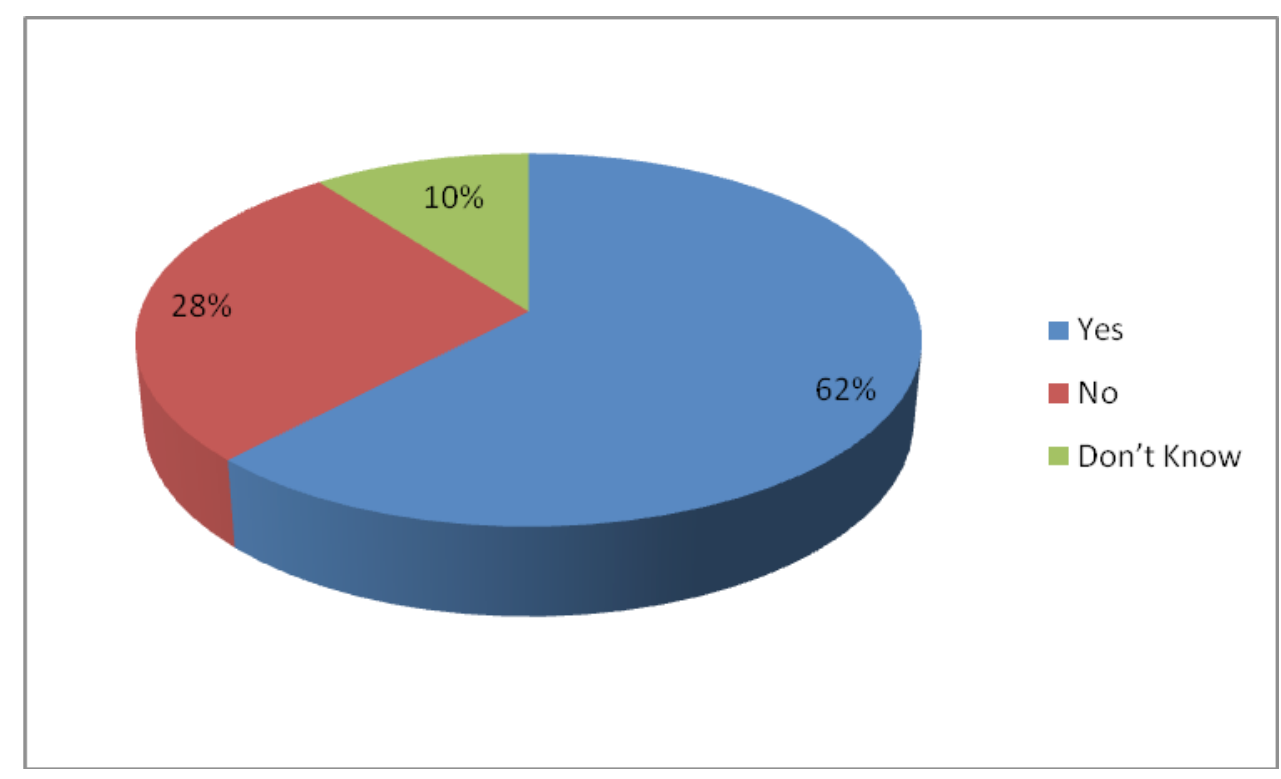

Fig. 1: Receptivity of dental students to tooth carving lectures early morning

Figure 1 shows the perception of dental students regarding tooth carving lectures in morning. Majority of students (i.e. $62 \%$ ) were more receptive to having tooth carving lectures early morning. However, about one third of students didn't agree with the same and reasons for the same needs to be explored 


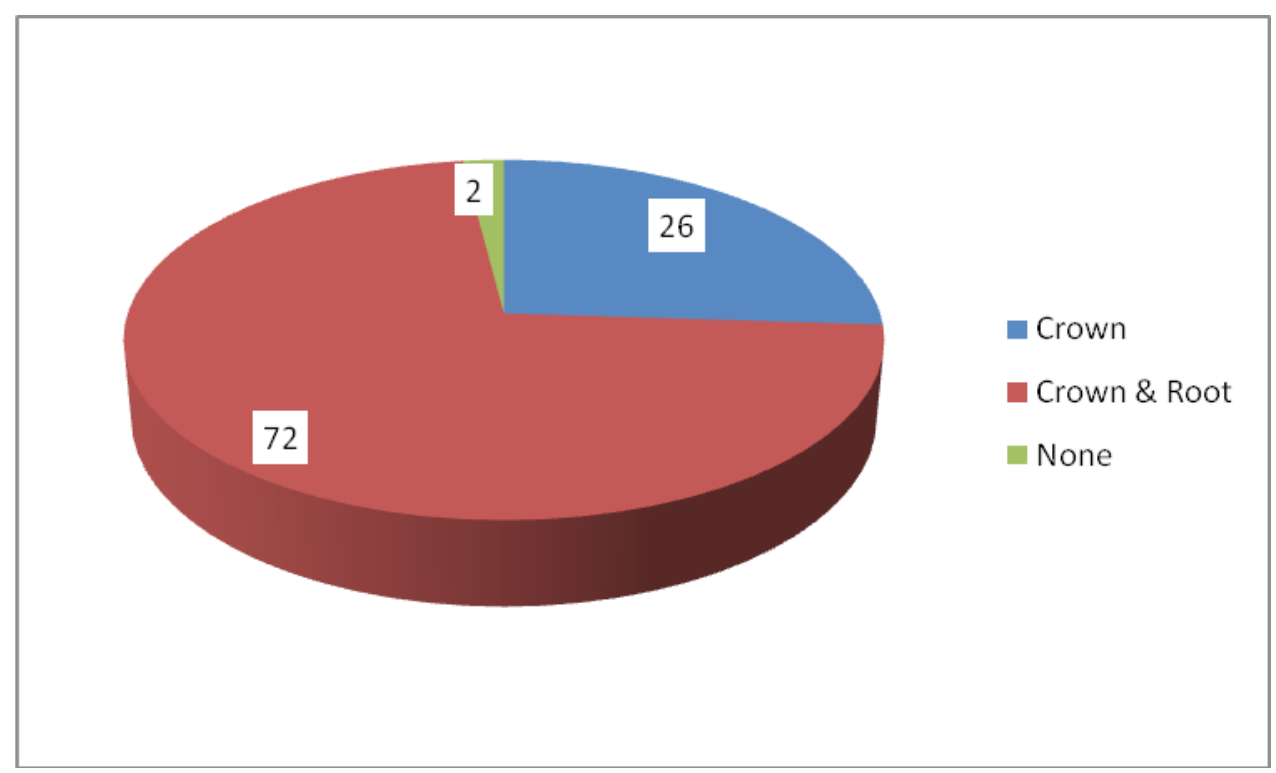

Fig. 2: Perception of dental students regarding part of tooth anatomy crucial for clinical subject

Figure 2 shows the perception of dental students regarding part of tooth anatomy crucial for clinical subject. While about $26 \%$ students were of the opinion that understanding the anatomy of Crown of tooth was crucial for clinical practice in later years, majority of students perceived that knowing the anatomy of both crown and root was crucial.

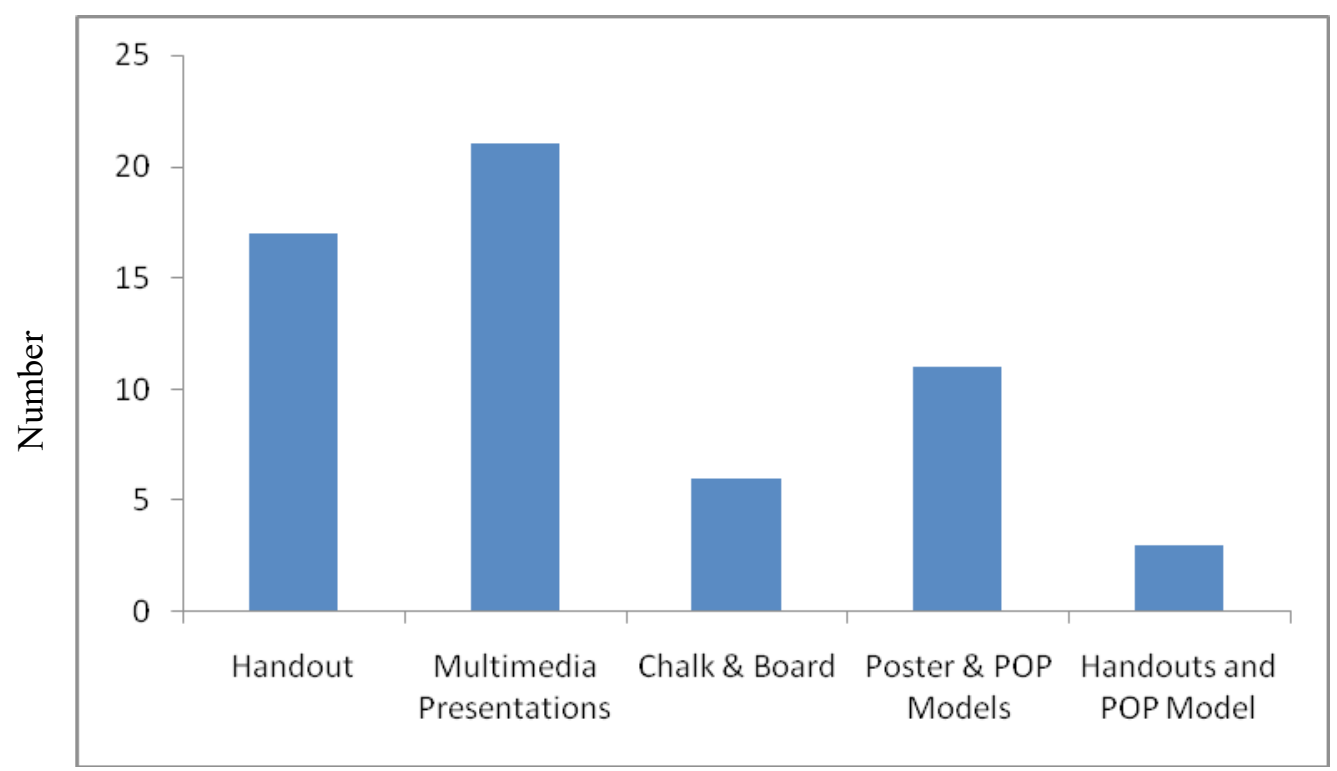

Fig. 3: Perception of dental students regarding educational aids preferable for learning carving

Figure 3 shows the perception of dental students with regards to the different available education aids for better understanding and learning of tooth carving. Majority of students perceived multimedia presentations were the most effective educational aid for teaching tooth carving. Chalk and board didn't find much preference. Majority of students perceived that having handouts of presentations and POP models will be beneficial to them in learning tooth carving. 


\section{Discussion}

In the present study a total of 58 dental students participated of which 40 were $3^{\text {rd }}$ year dental students and the rest were $2^{\text {nd }}$ year students. All students had exposure to carving tooth.

In our study both male and female students perceived that video demonstration of tooth carving would be more useful. Male students compared to females had a higher preference for video demonstration of tooth carving. Similar results were reported in a previous study by Yara Oweis et al where many students found video demonstration of tooth carving to be very valuable if used in addition to live demonstrations. ${ }^{3}$ Many students asked for the videos to be made available for them at home to be used while practicing outside lab hours. Another study by JP Ennes et al found that most students agreed that the wax models and technique demonstration videos aid in understanding the stages of the technique. ${ }^{4}$

In our study $82 \%$ male students perceived that dental carving will be helpful in their clinical practice, about $39 \%$ (i.e. more than one third) of female students had no idea, whether dental carving will be helpful in their clinical practice. Similar findings were reported in a previous study by Mayank $\mathrm{T}$ et al, where majority $62.3 \%$ of survey respondents agreed that carving influenced their knowledge of tooth anatomy. They believed that carving was helpful in restorative dentistry $(62.6 \%)$, understanding dental occlusion (53.8\%) and overall improved their clinical skills $(65 \%){ }^{5}$

The findings of our study reveal that majority of male and female students perceived that having a collection of 32 natural teeth in the department will help more in better understanding of tooth carving. Previously published literature has reported that some educators believe that the tooth anatomy can be learned by collecting and studying of intact extracted teeth. ${ }^{6}$

About $82 \%$ of both male and female students perceived that course content on carving was adequate. However, $10 \%$ students did not agree to the same and reasons for the same needs to be looked in. Majority of both male and female students were of the opinion that attending workshops would improve their knowledge of carving. More female students compared to males were interested in attending workshop on tooth carving.This is in accordance with study conducted by Abu et $\mathrm{al}^{1}$. In doing this their horizon will broaden about the subject and the students might find the monotonous carving interesting this further lays their foundation for being better clinicians in future .

In our study majority of students perceived multimedia presentations were the most effective educational aid for teaching tooth carving. Chalk and board didn't find much preference. Majority of students perceived that having handouts of presentations and Plaster of paris models will be beneficial to them in learning tooth carving. A previous study by Maggio MP et al reported that interactive media module was just as effective as the traditional classroom method for successful dissemination of foundational knowledge in dental morphology. The online module was found to positively engage the students and was preferred by students, however it was not regarded as a total replacement for the traditional course.

\section{Conclusion}

There is a need to revise the curriculum emphasizing on the utility of tooth carving in clinical practice. Also there is a need to adopt new innovative method at teaching dental carving, improving on carver design and enriching the course content with emphasis on competency and skills since many students even after having exposure to carving felt the need for further workshops. The training of skills of dental anatomy/tooth morphology can be enhanced using various current technologies like computer animated graphics, implementation of CAL programs, 3D images, digital atlases, photorealistic 3D models of human teeth and NEVO scanner with E4D compare software. ${ }^{1}$

\section{Conflict of Interest: Nil}

\section{Source of Funding: Nil}

Ethical Clearance: Ethical Clearance was not required.

\section{Reference}

1. Abu ER, Ewan K, Foley J, Oweys Y, Jayasinghe J. Self-directed study and carving tooth models for learning tooth morphology: Perceptions of students at the University of Aberdeen, Scotland. J Dent Educ. 2013; 77(9):1147-53.

2. Obrez A, Briggs C, Buckman J, Goldstein L, Lamb C, Knight WG. Teaching clinically relevant dental anatomy in the dental curriculum: description and assessment of an innovative module. J Dent Educ. 2011; 75 (6):797-804. 
3. Yara Oweis, Nadia Eriefej, Rasha Abu Eid Students' Perceptions of Dental Anatomy Course at The University of Jordan.2015. J Med J 2015; Vol. 49 (3):147- 154

4. Jussara Peixoto Ennes, Albert Schiaveto Souza, Inara Pereira da Cunha, Rayssa Pereira Nacasato, Dâmilie Catharine Monteiro Gardim. Teaching tools in dental carving: models, virtual resources, and interactivity. Revista da ABENO, 2018; $18(1): 45-55$.
5. T Meghanand. Etal. The Perceived Relevance of Tooth Carving in Dental Education: Views of Practicing Dentists and Faculty in West India Education for Health, 2014; Volume 27 (3): p-238242.

6. Okeson J, Buckman J. Curricular guidelines for teaching dental anatomy. J Dent Educ 1981; 45:540-2.

7. Maggio, M.P., K. Hariton-Gross, and J. Gluch, The use of independent, interactive media for education in dental morphology. J Dent Educ, 2012; 76 (11): p. $1497-511$. 